Vol. 2 No.2 Juni 2020

Ensiklopedia Social Review

http://jurnal.ensiklopediaku.org

\title{
PENDAPATAN ASLI DAERAH UNTUK PEMBANGUNAN DAERAH YANG BERKELANJUTAN DI INDONESIA
}

\author{
NOVA YARSINA \\ Sekolah Tinggi Ilmu Hukum Putri Maharaja Payakumbuh \\ novayarsina@yahoo.com
}

\begin{abstract}
This objective is to examine the original income of the region for sustainable regional development in Indonesia, using normative legal research. Regional government finance is a very decisive factor in the administration of regional government. The financial capacity of a region is determined by the existence of a source of regional income and its level of lucrative. The level of a local source of revenue is determined by the extent to which the basis for imposing taxes is responsive to inflation, population growth and economic growth. Generally in developed countries that implement decentralization policies tend to give greater authority to the regions to manage sources of revenue that are lucrative. On the other hand, in developing countries, financial resources are controlled by the central government. Local governments only manage financial resources that are less potential.
\end{abstract}

Keywords: Regional Original Revenue, Regional Development, Sustainable.

\begin{abstract}
Abstrak: Tujuan ini untuk meneliti pendapatan asli daerah untuk pembangunan daerah yang berkelanjutan di Indonesia, dengan menggunakan penelitian hukum normatif. Keuangan pemerintah daerah merupakan faktor yang sangat menentukan dalam penyelenggaraan pemerintahan daerah. Kemampuan keuangan daerah ditentukan oleh adanya sumber pendapatan daerah dan tingkat lukratifnya. Tingkat lukratif tidaknya sumber pendapatan daerah ditentukan oleh sejauh mana dasar pengenaan pajak responsif terhadap inflasi, pertumbuhan penduduk dan pertumbuhan ekonomi. Umumnya di negara-negara maju yang menerapkan kebijakan desentralisasi cenderung memberikan kewenangan yang lebih besar kepada daerah untuk mengelola sumbersumber pendapatan yang lukratif. Sebaliknya di negara-negara berkembang sumbersumber keuangan yang lukratif dikuasai oleh pusat. Pemerintah daerah hanya mengelola sumber-sumber keuangan yang kurang potensial.
\end{abstract}

Kata Kunci: Pendapatan Asli Daerah, Pembengunan Daerah, Berkelanjutan.

\section{A. Pendahuluan}

Sumber keuangan daerah selalu terkait dengan hubungan keuangan antara pemerintah pusat dengan pemerintah daerah. Dalam hal daerah harus mampu menyelenggarakan kewenangan yang dimiliki maka harus ada perimbangan keuangan yang adil dan transparan antara pusat dan daerah. Untuk dapat mencapai kondisi ini terdapat tiga aspek yang harus dipertimbangkan yaitu: Pertama, sejauh mana daerah diberi sumber-sumber keuangan yang cukup terutama pajak daerah dan retribusi daerah. Kedua, sejauh mana daerah memperoleh akses pada pendapatan-pendapatan yang bersumber dari bagi hasil pajak. Ketiga, sejauh mana daerah telah mendapatkan subsidi yang adil dan efektif dari pemerintah pusat (Hanif Nurcholis, 2005).

Hubungan keuangan antara pusat dan daerah merupakan cermin dari cara pandang suatu negara terhadap pemerintah daerahnya. Dalam hal ini terdapat dua pandangan (Bambang Juanda, 2013): Pertama, pandangan yang menyatakan bahwa 
pemerintah daerah merupakan formalisasi dan legalisasi dari keberadaan masyarakat yang sudah ada sebelumnya dalam struktur negara bangsa. Karena itu, pemerintah daerah dianggap telah memiliki sumber-sumber keuangan sendiri seperti pajak dan sumber pendapatan lain yang sudah ada sebelum ia menjadi bagian dari struktur negara bangsa. Atas dasar pandangan ini, maka yang dimaksud dengan hubungan antara pusat dan daerah adalah seberapa besar pusat mentransfer dana dalam bentuk alokasi kepada daerah. Contoh negara yang menganut pandangan ini adalah negara Inggris dan negara federal umumnya. Pada negara-negara tersebut pemerintah daerah sejak awal telah mempunyai sumber-sumber pendapatannya sendiri. Kedua, pandangan yang menganggap pemerintah daerah sebagai bagian dan alat pemerintah pusat untuk menjalankan kekuasaannya. Karena itu, penyelenggaraan pemerintahan daerah didanai seluruhnya oleh pemerintah pusat. Contoh negara yang menganut pandangan ini adalah negara Indonesia. Pemerintah daerah di Indonesia sebagian besar sumber pendapatannya berasal dari transfer dana dari pemerintah pusat (Bhenyamin Hoessein, 2002).

Undang-undang Nomor 23 Tahun 2014 tentang Pemerintahan Daerah sebagaimana telah diubah dengan Undang-Undang Nomor 9 Tahun 2015 (UU Pemda) dan Undang-Undang Nomor 33 Tahun 2004 tentang Perimbangan Keuangan Antara Pusat dan Daerah, merubah secara mendasar model pembiayaan pemerintah daerah. Konsepsi dasar model pembiayaan daerah menurut kedua undang-undang tersebut adalah penyerahan kewenangan pemerintahan kepada daerah baik menurut asas desentralisasi, dekonsentrasi dan tugas pembantuan harus diikuti biaya, perangkat dan tenaga yang memadai, agar daerah mampu menyelenggarakan semua kewenangan yang diserahkan tersebut. Dengan model penganggaran seperti itu maka pemerintah pusat tidak lagi menentukan secara subyektif dana tersebut, tapi mengalokasikan dana secara proporsional dan rasional kepada daerah agar pemerintah daerah mampu menyelenggarakan otonominya secara kreatif dan bertanggung jawab (Bhenyamin Hoessein, 2000). Melalui struktur pendanaan demikian, diharapkan pemerintah daerah makin mampu memberikan pelayanan prima kepada publik yang berujung pada penciptaan kesejahteraan masyarakat.

Undang-undang Nomor 23 Tahun 2014 tentang Pemerintahan Daerah sebagaimana telah diubah dengan Undang-Undang Nomor 9 Tahun 2015 (UU Pemda) mengatur tentang pembiayaan, penyelenggaraan tugas pemerintah daerah dan DPRD dalam rangka pelaksanaan asas desentralisasi yang dibiayai oleh Anggaran Pendapatan dan Belanja Daerah (APBD). Menurut Pasal 285 ayat (1) Undang-Undang Nomor 23 Tahun 2014 tentang Pemerintahan Daerah dinyatakan bahwa: Sumber pendapatan Daerah terdiri atas: a) pendapatan asli Daerah meliputi: pajak daerah; retribusi daerah; hasil pengelolaan kekayaan Daerah yang dipisahkan; dan lain-lain pendapatan asli Daerah yang sah; b) pendapatan transfer; dan c) lain-lain pendapatan Daerah yang sah. Pendapatan Asli Daerah adalah penerimaan daerah dari sektor pajak daerah, retribusi daerah, hasil perusahaan milik daerah, hasil pengelolaan kekayaan daerah yang dipisahkan, dan lain-lain pendapatan asli daerah yang sah.

\section{B. Metodologi Penelitian}

Penelitian merupakan suatu kegiatan ilmiah yang didasarkan pada metode, sistematika, dan pemikiran tertentu yang bertujuan untuk mempelajari satu atau beberapa gejala hukum tertentu dengan menganalisanya. Dalam melakukan penelitian hukum seyogyanya selalu meningkatkan dengan makna yang mungkin dapat diberikan kepada hukum. Penelitian ini adalah suatu penelitian yang bersifat E-ISSN: 2657-0300 Lembaga Penelitian dan Penerbitan Hasil Penelitian Ensiklopedia 133 P-ISSN: 2657-0319 
deskriptif analitis, yaitu suatu penelitian yang menggambarkan mengenai pendapatan asli daerah untuk pembangunan daerah yang berkelanjutan di Indonesia. Pendekatan utama yang digunakan dalam penelitian ini adalah pendekatan secara yuridis normatif. Penelitian hukum secara yuridis normatif yaitu mencari logisnya aturanaturan hukum, dimana hukum merupakan gejala normatif yang bersifat otonom dan lebih memfokuskan pada law ini books.

\section{Hasil dan Pembahasan}

\section{Sumber-Sumber Pendapatan Asli Daerah}

Sumber keuangan daerah yang utama adalah Pendapatan Asli Daerah (PAD). PAD adalah pendapatan yang diperoleh daerah dari penerimaan pajak daerah, retribusi daerah, laba perusahaan daerah dan lain-lain yang sah (Elektison Somi, 2006).

Pajak Daerah. Davey merumuskan pajak daerah adalah (Frank Feulner, 2005): 1) Pajak yang dipungut oleh pemerintah daerah dengan pengaturan dari daerah sendiri; 2) Pajak yang dipungut berdasarkan peraturan nasional tetapi penetapan tarifnya dilakukan oleh pemerintah daerah; 3) Pajak yang ditetapkan dan atau dipungut oleh pemerintah daerah. Sedangkan menurut Undang-Undang Nomor 34 Tahun 2000 tentang Pajak dan Retribusi Daerah yang dimaksud dengan pajak daerah adalah: Iuran wajib yang dilakukan oleh orang pribadi atau badan kepada daerah tanpa imbalan langsung yang seimbang, yang dapat dipaksakan berdasarkan peraturan perundangundangan yang berlaku, yang digunakan untuk membiayai penyelenggaraan pemerintahan daerah dan pembangunan daerah.

Jenis-jenis pajak daerah dan tarifnya adalah sebagai berikut: 1) Jenis pajak daerah yang dipungut Provinsi: Pajak Kendaraan Bermotor dan Kendaraan di Atas Air (PKB-KAA) dengan tarif 5\%; Bea Balik Nama Kendaraan Bermotor dan Kendaraan di Atas Air (BBNKB-KAA) dengan tarif 10\%; Pajak Bahan Bakar Kendaraan Bermotor (PBBKB) dengan tarif 5\%; dan Pajak Pengambilan dan Pemanfaatan Air Bawah Tanah dan Air Permukaan (P3ABT dan AP) dengan tarif 20\%. Demi rasa keadilan dan asas pemerataan maka undang-undang mengatur Bagi Hasil Pajak dan Realokasi Pajak daerah provinsi dengan daerah kabupaten/kota. Pajak provinsi yang bersumber dari PKB-KAA dan BBNKB-KAA, P3ABT dan AP sebagian diserahkan kepada kabupaten/kota dengan ketentuan sebagai berikut: a) Minimum $30 \%$ dari penerimaan PKB-KAA dan BBNKB-KAA; b) Minimum 70\% dari penerimaan PBB-KB-KAA; dan c) Minimum $70 \%$ dari penerimaan P3ABT dan AP.

Pengalihan bagian penerimaan pajak provinsi tersebut lebih lanjut diatur dan ditetapkan berdasarkan Peraturan Daerah Provinsi dengan memperhatikan aspek pemerataan dan potensi antar daerah kabupaten/kota dalam provinsi yang bersangkutan. Sedangkan penggunaan bagian daerah kabupaten/kota diatur dan ditetapkan oleh daerah itu sendiri (Juanda Nawawi, 2015). Penerimaan pajak kabupaten juga harus dialokasikan minimum $10 \%$ untuk kepentingan desa. Pengaturan mengenai alokasi pajak tersebut didasarkan pada aspek pemerataan dan potensi yang dimiliki oleh desa-desa yang bersangkutan. Penerimaan pajak kabupaten/kota dalam suatu provinsi yang terkonsentrasi pada kabupaten/kota tertentu, gubernur mengambil kebijakan untuk membagikan sebagian hasil penerimaan pajak tersebut kepada kabupaten/kota lainnya.

Jenis pajak daerah yang dipungut Kabupaten/Kota: a) Pajak hotel dengan tarif $10 \%$; b) Pajak restoran dengan tarif 10\%; c) Pajak hiburan dengan tarif 35\%; d) Pajak 
reklame dengan tarif 25\%; e) Pajak penerangan jalan dengan tarif 10\%; f) Pajak pengambilan bahan galian golongan $\mathrm{C}$ dengan tarif 20\%; dan g) Pajak parkir dengan tarif $20 \%$.

Retribusi. Menurut Undang-Undang Nomor 34 Tahun 2000 retribusi adalah: Pungutan daerah sebagai pembayaran atas jasa atau pemberian izin tertentu yang khusus disediakan dan/atau diberikan oleh pemerintah daerah untuk kepentingan orang pribadi atau badan. Yang termasuk golongan dan jenis retribusi daerah adalah: 1) Yang ditetapkan dengan Peraturan Pemerintah: a) Retribusi Jasa Umum; b) Retribusi Jasa Usaha; c) Retribusi Perizinan; dan 2) Yang ditetapkan dengan Peraturan Daerah: retribusi selain yang ditetapkan dengan Peraturan Pemerintah.

Retribusi ditetapkan dengan Peraturan Daerah. Tarif retribusi ditinjau kembali secara berkala dengan mempertimbangkan prinsip dan sasaran penetapan tarif. Hasil penerimaan hasil retribusi tertentu kabupaten, sebagian diperuntukkan pada desa. Penetapannya diatur dengan Perda Kabupaten dengan memperhatikan aspek keterlibatan desa dalam penyediaan layanan tersebut (Ni Desak Putu Ayu Lestari, 2014).

Laba BUMD dan Hasil Pengelolaan Kekayaan lainnya. Bagi daerah yang memiliki BUMD seperti Perusahaan Daerah Air Minum (PDAM), Bank Pembangunan Daerah (BPD), Badan Kredit Kecamatan, Pasar, tempat hiburan/rekreasi, vila, pesanggrahan dan lain-lain keuntungannya merupakan penghasilan bagi daerah yang bersangkutan (Ni Desak Putu Ayu Lestari, 2014).

Lain-lain PAD yang sah. Lain-lain PAD yang sah meliputi (Ni Desak Putu Ayu Lestari, 2014): 1) Hasil penjualan kekayaan daerah yang tidak dipisahkan; 2) Jasa giro; 3) Pendapatan bunga; 4) Keuntungan selisih nilai tukar rupiah terhadap mata uang asing; dan 5) Komisi, potingan ataupun bentuk lain sebagai akibat dari penjualan dan/atau pengadaan barang dan/atau jasa oleh daerah.

\section{Fungsi Pendapatan Asli Daerah Untuk Pembangunan Daerah Yang Berkelanjutan}

Penyelenggaraan fungsi pemerintahan daerah akan terlaksana secara optimal apabila penyelenggaraan urusan pemerintahan diikuti dengan pemberian sumbersumber penerimaan yang cukup kepada daerah, dengan mengacu kepada Undangundang tentang Perimbangan Keuangan antara Pemerintah Pusat dan Pemerintah Daerah, dimana besarnya disesuaikan dan diselaraskan dengan pembagian kewenangan antara pemerintah dan daerah. Semua sumber keuangan yang melekat pada setiap urusan pemerintah yang diserahkan kepada daerah menjadi sumber keuangan daerah (Nurhasmah, Nadirsyah dan Syukriy Abdullah, 2015).

Daerah diberikan hak untuk mendapatkan sumber keuangan yang antara lain berupa kepastian tersedianya pendanaan dari pemerintah sesuai dengan urusan pemeirntah yang diserahkan; kewenangan memungut dan mendayagunakan pajak dan retribusi daerah dan hak untuk mendapatkan bagi hasil dari sumber-sumber daya nasional yang berada di daerah dan dana perimbangan lainnya; hak untuk mengelola kekayaan daerah dan mendapatkan sumber-sumber pembiayaan. Dengan pengaturan tersebut, dalam hal ini pada dasarnya Pemerintah menerapkan prinsip "uang mengikuti fungsi".

Di dalam Undang-Undang mengenai Keuangan Negara, terdapat penegasan di bidang pengelolaan keuangan, yaitu bahwa kekuasaan pengelolaan keuangan negara adalah sebagai bagian dari kekuasaan pemerintahan dan kekuasaan pengelolaan keuangan negara dari presiden sebagian diserahkan kepada gubernur/bupati/walikota E-ISSN: 2657-0300 Lembaga Penelitian dan Penerbitan Hasil Penelitian Ensiklopedia $\quad 135$ 
selaku kepala pemerintah daerah dalam kepemilikan kekayaan daerah yang dipisahkan. Ketentuan tersebut berimplikasi pada pengaturan pengelolaan keuangan daerah, yaitu bahwa gubernur/bupati/walikota bertanggung jawab atas pengelolaan keuangan daerah sebagai bagian dari kekuasaan pemerintahan daerah. Dengan demikian pengaturan pengelolaan dan pertanggungjawaban keuangan daerah melekat dan menjadi satu dengan pengaturan pemerintahan daerah, yaitu dalam Undang-undang mengenai Pemerintah Daerah.

Prinsip dasar untuk mengenakan retribusi biasanya didasarkan pada full cost atas pelayanan-pelayanan yang disediakan. Akan tetapi adanya tingkat perbedaan pembiayaan pelayanan serta faktor sosial, politik dan kepentingan yang mempengaruhi, maka dalam menentukan dasar pembebanan retribusi harus melalui kompromi. Hal ini dapat mengakibatkan retribusi dikenakan di bawah full cost-nya dan kekurangannya disubsidi dari penerimaan umum. Ada empat alasan utama mengapa hal ini terjadi, yaitu (Kesit Bambang Prakoso, 2005):

Pertama, timbul apabila suatu pelayanan pada dasarnya adalah merupakan suatu public good yang disediakan karena keuntungan kolektifnya, tetapi suatu retribusi harus dikenakan untuk mendisiplinkan pemakai. Pembebanan kemudian harus ditetapkan pada suatu tingkat kalkulasi untuk menghindari pemborosan tetapi memperkenankan tingkat konsumsi minimum yang utama oleh seluruh kelompokkelompok pendapatan. Pembebanan resep kesehatan (dokter) untuk obat-obat generik dan non generik atau tingkat saluran pipa air minum mungkin jatuh pada kategori ini.

Kedua, untuk subsidi terjadi apabila suatu pelayanan merupakan bagian dari swasta dan sebagian lagi merupakan bagian dari public good, di mana hal itu terutama memberikan keuntungan pada individu pamakai, tetapi konsumsinya perlu didorong bagi kepentingan tabungan atau keuntungan masyarakat. Contoh yang paling menyolok adalah di mana tarif kereta api atau bis disubsidi guna mendorong masyarakat untuk menggunakan angkutan umum daripada angkutan swasta, sebagai alat untuk menurunkan kemacetan-kemacetan lalu lintas dan pengeluaran biaya perawatan jalan.

Ketiga, pelayanan di mana seluruhnya private good yang dapat disubsidi jika hal ini merupakan permintaan yang populer dan penguasa enggan menghadapi masyarakat dengan full cost-nya. Hal ini sering dilaksanakan bagi penyediaan fasilitas-fasilitas rekreasi misal taman rekreasi, pantai, kolam renang, gedung seni atau gedung pertunjukan. Hal itu dapat pula dipertanyakan bahwa dengan memiliki penduduk yang sehat atau suatu orkestra tingkat tinggi, adalah merupakan keuntungan bersama (collective benefit). Misalnya, disediakan lapangan bowling (bowling greeens) bukan tempat main bowling.

Keempat, pelayanan yang sebenarnya merupakan private good tetapi mungkin perlu disubsidi sebab hal itu dianggap sebagai suatu kebutuhan dasar manusia dan kelompok-kelompok berpenghasilan rendah, serta tidak mungkin mengharapkan mereka untuk memenuhi full cost-nya atas pelayanan tersebut (Yuliandri, 2010). Di dalam memberikan contoh-contoh perlu berhati-hati karena konsepsi daripada kebutuhan pokok adalah benar-benar subjektif dan relatif bagi standar kehidupan yang umum. Keharusan menurut undang-undang untuk menyediakan para tunawisma dengan perumahan kota praja dengan sewa yang disubsidi dilihat sebagian memenuhi kebutuhan dasar di daerah, baik kewajiban maupun standar kebutuhan dasar dapat dianggap sebagai yang realistis di banyak negara Dunia Ketiga. 
Bagi orang-orang tertentu, subsidi merupakan penyimpangan. Dengan alasan, hal tersebut dapat menyebabkan inefisiensi baik karena penghamburan sumber-sumber bagi penyediaan yang bukan merupakan biaya yang efektif, atau karena hal tersebut memberikan kepada seluruh konsumen apakah mereka perlu disubsidi atau tidak. Oleh karena itu saran diajukan, pertama, pengurangan subsidi sebagian hanya dilaksanakan kepada kategori-kategori pemakai tertentu, group-group berpenghasilan rendah, anakanak, orang tua-orang tua dan sebagainya.

Atau kedua, subsidi sebagiannya hanya diberikan kepada tingkat konsumsi minimum, di atas harga pasar harus dilakukan. Suplai air minum 40 liter per hari pertama kepada seseorang harus dikenakan retribusi, misalnya dengan rate yang rendah di bawah biaya, konsumsi di atas level ini akan dikenakan tarif pada marginal cost penuh. Hal ini kenal oleh Bank Dunia sebagai the lifeline approach. Tarif air bersih di Hongkong dan Tokyo misalnya didasarkan pada prinsip ini. Pelaksanaan salah satu dari approach tersebut di atas tergantung terutama pada kelayakan administrasi dan tekanan politis. Akan lebih mudah mengidentifikasi yang muda dan yang tua, jika setiap orang memiliki angka kelahiran akan lebih mudah mengidentifikasi golongan miskin apabila sebagian besar penduduk mempunyai pendapatan berupa gaji dan sebagian kecil dikualifikasikan berupa lain-lain. The lifeline alternative juga didasarkan pada kemampuan untuk mengukur kecukupan konsumsi. Di dalam kondisi-kondisi yang lain persyaratan-persyaratan untuk memberi subsidi lebih mudah untuk ditentukan.

Tekanan politis merupakan hal yang penting, sebab pengarah golongan berpendapatan menengah dan tinggi sering mendominasi pengarahan daripada subsidi dan keuntungan-keuntungannya. Rumah-rumah yang disubsidi di negara-negara Dunia Ketiga sering bertambah pada kelas-kelas menengah daripada miskin, investasi angkutan mungkin lebih memihak pemilik kendaraan. Subsidi pendidikan tinggi dalam praktek mungkin tersedia sebagian besar untuk anak-anak dari group-group berpenghasilan tinggi dan mungkin memperkuat politik mereka dan kekuasaan profesional (Otong Rosadi, 2015).

Di dalam beberapa hal retribusi mungkin lebih didasarkan pada recovering daripada full cost dari suatu pelayanan, yaitu dasar mencari keuntungan. Setidaktidaknya ada tiga kasus di mana hal ini bisa terjadi, yaitu (Syamsu Kamardan M.Y Tiyas Tinov, 2013): Pertama, di mana retribusi dikenakan untuk tujuan-tujuan pengaturan yang melibatkan sedikit biaya langsung. Licensing fees atau meteran parkir merupakan contoh.

Kedua, retribusi mungkin dikenakan pada tingkat di atas biaya guna memperkuat pengaruh disiplin mereka atas konsumsi. Retribusi telepon mungkin dibagi-bagi sesuai dengan perhatian untuk tidak mendorong kemacetan pada puncak-puncak jam-jam siness. Parking fees atau daerah licencing fees mungkin dikenakan pada tingkat penghukuman, seperti di Singapura yang mengeluarkan kendaraan pribadi dari pusat kota. Akhirnya suatu pelayanan mungkin mempunyai permintaan yang cukup banyak dan penduduk ingin membayar tinggi untuk hal itu karena tingkat keperluannya atau popularitas dan keterbatasan suplainya. Hal ini mungkin dioperasikan khususnya di mana suatu pelayanan yang sama dikaitkan juga kepada penyediaan biaya perusahaanperusahaan swasta (Yuslim, 2014). Retribusi di atas biaya dapat juga diukur dalam situasi yang demikian jika kelebihan penerimaan ditanamkan kembali kepada perluasan pelayanan sehingga suatu jumlah yang besar mempunyai jalur itu.

Suatu contoh yang baik untuk hal ini dikaitkan pada penyediaan rumah pemerintah di banyak negara Dunia Ketiga di mana suplai yang tidak mencukupi E-ISSN: 2657-0300 Lembaga Penelitian dan Penerbitan Hasil Penelitian Ensiklopedia 137 
menimbulkan pemerasan sewa di dalam sektor swasta dan di mana para penghuni perumahan milik Pemerintah mungkin relatif dianggap sebagai hak-hak istimewa. Akan tetapi retribusi di atas biaya adalah analog dengan perpajakan. Timbulnya dan pemerataannya harus dipertimbangkan. Seksi-seksi mana di masyarakat yang membayar lebih dari suatu pelayanan dan seksi-seksi yang mana menerima keuntungan dari kelebihan penerimaan. Retribusi parkir yang tinggi mungkin pantas bagi para pemilik mobil yang umumnya merupakan golongan masyarakat yang berpenghasilan tinggi. Mencari keuntungan di luar para pemakai bis melalui jawatan transportasi, lahan-lahan pada stasiun bis, dan lain-lain mungkin sebagain besar merupakan penghukuman golongan miskin.

Untuk dapat menentukan dasar pengenaan retribusi atau objek retribusi terhadap potensi pendapatan daerah, maka perlu dilakukan penilaian terhadap potensi pendapatan daerah tersebut. Ada beberapa kriteria yang harus dipenuhi agar potensi pendapatan daerah yang dapat dikenai retribusi, yaitu: kecukupan dan elastisitas, keadilan, kemampuan administrasi, kesepakatan politik dan penilaian retribusi oleh pemerintah daerah.

\section{Penutup}

Keuangan pemerintah daerah merupakan faktor yang sangat menentukan dalam penyelenggaraan pemerintahan daerah. Kemampuan keuangan daerah ditentukan oleh adanya sumber pendapatan daerah dan tingkat lukratifnya. Tingkat lukratif tidaknya sumber pendapatan daerah ditentukan oleh sejauh mana dasar pengenaan pajak responsif terhadap inflasi, pertumbuhan penduduk dan pertumbuhan ekonomi. Umumnya di negara-negara maju yang menerapkan kebijakan desentralisasi cenderung memberikan kewenangan yang lebih besar kepada daerah untuk mengelola sumbersumber pendapatan yang lukratif. Sebaliknya di negara-negara berkembang sumbersumber keuangan yang lukratif dikuasai oleh pusat. Pemerintah daerah hanya mengelola sumber-sumber keuangan yang kurang potensial. Pendapatan asli daerah adalah kunci terhadap pembangunan daerah yang berkelanjutan di Indonesia, sehingg mewujudkan daerah-daerah yang sejahtera dan berimplikasi pada negara.

\section{Daftar Pustaka}

Bambang Juanda, et-al, Evaluasi Regulasi Pengelolaan Keuangan Daerah dan Pengaruhnya Terhadap Upaya Peningkatan Kualitas Belanja Daerah, Laporan Hasil Penelitian, Kementerian Keuangan, Jakarta, 2013.

Bhenyamin Hoessein, Kebijakan Desentralisasi, Jurnal Administrasi Negara Volume II, Nomor 2, 2002.

Bhenyamin Hoessein, Hubungan Penyelenggaraan Pemerintahan Pusat dengan Pemerintahan Daerah, Jurnal Bisnis dan Birokrasi, Nomor 1, Volume 1, 2000.

Elektison Somi, Pengawasan Pengelolaan Keuangan Daerah Dalam Sistem Pemerintahan di Indonesia, Disertasi, Universitas Padjadajran, Bandung, 2006.

Frank Feulner, Menguatkan Demokrasi Perwakilan di Indonesia: Tinjauan Kritis Terhadap DPD, Jurnal Hukum Jentera, Edisi 8 Tahun III, 2005.

Hanif Nurcholis, Teori dan Praktik Pemerintahan dan Otonomi Daerah, Gramedia Widiasarana Indonesia, Jakarta, 2005. 
Juanda Nawawi, Analisis Hubungan DPRD dan Pemerintah Daerah dalam Pembuatan Kebijakan Kemiskinan di Provinsi Sulawesi Barat, Jurnal Ilmu Pemerintahan Government, Volume 8, Nomor 1, 2015.

Kesit Bambang Prakoso, Pajak dan Retribusi Daerah, UII Press, Yogyakarta, 2005.

Ni Desak Putu Ayu Lestari, Perencanaan dan Penganggaran Pada Badan Pengembangan Wilayah Surabaya-Madura (BPWS), Jurnal Ilmu Riset, Volume 3, Nomor 2, 2014.

Nurhasmah, Nadirsyah dan Syukriy Abdullah, Pengaruh Peran Dewan Perwakilan Rakyat Daerah (DPRD) Kompetensi Eksekutif, Dan Komitmen Organisasi Terhadap Penyusunan Anggaran Pendapatan Anggaran dan Belanja Daerah Kabupaten Aceh Utara, Jurnal Magister Akuntansi Pascasarjana Universitas Syiah Kuala, Volume 4, Nomor 1, 2015.

Otong Rosadi, Konstitusionalitas Pengaturan Pemerintahan Daerah di Indonesia: Suatu Eksperimen yang Tidak Kunjung Selesai, Padjadjaran Jurnal Ilmu Hukum, Volume 2, Nomor 3, 2015.

Syamsu Kamardan M.Y Tiyas Tinov, Hubungan Pemerintah Daerah-DPRD Dalam Pembahasan Ranperda, Jurnal Demokrasi dan Otonomi Daerah, Volume 11, Nomor 2, 2013.

Yuslim, Kewenangan Gubernur Sebagai Wakil Pemerintah Dalam Penyelenggaraan Pemerintahan Kabupaten/Kota Menurut Undang-Undang Dasar 1945, Ringkasan Disertasi, Universitas Andalas, Padang, 2014.

Yuliandri, Asas-Asas Pembentukan Peraturan Perundang-Undangan Yang Baik Gagasan Pembentukan Undang-Undang Berkelanjutan,PT. Raja Grafindo Persada, Jakarta, 2010 